Article

\title{
Construction of a Self-Powered System for Simultaneous In Situ Remediation of Nitrate and Cr(VI) Contaminated Synthetic Groundwater and River Sediment
}

\author{
Limei Han, Rui Liu, Miao Li *, Ning Zhang ${ }^{\circledR}$, Fang Zhang and Xiang Liu \\ School of Environment, Tsinghua University, Beijing 10084, China; wlhanlimei@163.com (L.H.); \\ ray45260279@gmail.com (R.L.); dtlzhangning@163.com (N.Z.); fangzhang@mail.tsinghua.edu.cn (F.Z.); \\ x.liu@mail.tsinghua.edu.cn (X.L.) \\ * Correspondence: miaoli@tsinghua.edu.cn
}

Received: 15 July 2018; Accepted: 1 August 2018; Published: 8 August 2018

\begin{abstract}
A novel self-powered system was constructed to in situ remove nitrate and $\mathrm{Cr}(\mathrm{VI})$ from synthetic groundwater and achieve river sediment remediation simultaneously. The sediment organic matter in an anodic chamber was used as a carbon source to provide self-powered energy to reduce the cathode's contaminants. With the acceptance of protons and electrons, nitrate and $\mathrm{Cr}(\mathrm{VI})$ were transformed into nitrite and $\mathrm{Cr}(\mathrm{III})$, respectively. In a $72 \mathrm{~h}$ test with both nitrate and $\mathrm{Cr}(\mathrm{VI})$ present, nitrate was removed at a rate of $70.96 \mathrm{mg} / \mathrm{m}^{3} \cdot \mathrm{h}$ and $\mathrm{Cr}(\mathrm{VI})$ at a rate of $8.95 \mathrm{mg} / \mathrm{m}^{3} \cdot \mathrm{h}$. When a phosphate buffer was used in the test, their removal rates were changed to $140.83 \mathrm{mg} / \mathrm{m}^{3} \cdot \mathrm{h}$ and $8.33 \mathrm{mg} / \mathrm{m}^{3} \cdot \mathrm{h}$, respectively. The results showed that the self-powered system could achieve the simultaneous reduction of nitrate and $\mathrm{Cr}(\mathrm{VI})$, although the presence of $\mathrm{Cr}(\mathrm{VI})$ hindered nitrate reduction. This system could realize simultaneous in situ groundwater and sediment remediation, with no need for additional energy or materials.
\end{abstract}

Keywords: self-powered system; groundwater remediation; denitrification; $\mathrm{Cr}(\mathrm{VI})$ removal; cyclic voltammetry $(\mathrm{CV})$

\section{Introduction}

Groundwater is an important water resource, utilized as drinking water and irrigation water in many countries. Because of the importance of groundwater, its quality has received much research attention [1,2]. Nitrate and chrome are known as significant contaminants in the environment because of their tendency to occur in forms (e.g., $\mathrm{Cr}(\mathrm{VI})$ ) and derivatives which are harmful to people and animals [3-5]. Large increases in the overuse of nitrogen fertilizers and the discharge of wastewaters [6,7] have led to nitrate contamination. Research has shown that fly ash disposal, leather industries, mining industries, and natural contamination have caused chrome accumulation in the environment [8-10]. In China, many rivers receive water contaminated with heavy metals, as well as domestic wastewater discharge. Although these contaminants have not been discharged into groundwater directly, they can permeate into groundwater due to their strong mobility. Many studies have shown that nitrate and chrome concentrations in groundwater are higher than the ambient levels $[3,11]$. Several methods have been used for the simultaneous removal of nitrate and hexavalent chromium from groundwater and soils, including biofilm reactors [12], membrane reactors [13], phytoremediation [14], three-dimensional electrocatalytic reactors [15] and bio-electrochemical systems [16]. These methods require the input of additional energy or substances. The treatment of 
nitrate and $\mathrm{Cr}(\mathrm{VI})$ coexisting in groundwater using 3-dimensional bio-electrochemical systems (BES) has been achieved, but it still needs applied potentials [16].

Aquatic sediment acts as a repository for multiple pollutants in rivers and lakes, and as a significant source of internal pollutants. Pollutants include organic matter, metal contaminants, and inorganic salts [17-19]. Organic substances play an important role in the deterioration of water quality because when it catabolized, the dissolved oxygen in water consumed, thus results in an anoxic or anaerobic condition of water. Conditions, such as water disturbances and temperature $/ \mathrm{pH}$ changes can lead to contaminants being released from the sediments [20].

Many strategies have been proposed for the remediation of sediments. Although ex situ remediation methods, such as dredging and dry excavation can control the release of pollutants, these methods are harmful to the water environment and are also a waste of resources [19,21]. Since there are large quantities of organic matter in the sediments [22,23], with the use of sediment as a carbon source in sediment microbial fuel cells systems (sMFC) [24,25], the organic matter can be used as a carbon source, as well as an energy source for microorganisms to reduce other contaminants. To our best knowledge, the research of simultaneous treatment of contaminated groundwater and the remediation of sediment achieved without inputting additional energy and materials, has not been reported yet.

In this study, a self-powered system was constructed for the in situ removal of nitrate and $\mathrm{Cr}(\mathrm{VI})$ from synthetic groundwater, and the remediation of sediment simultaneously. Using Ti wire and proton exchanger, for the connection of river sediment rich in organic matter and the nearby nitrate and $\mathrm{Cr}(\mathrm{VI})$ contaminated groundwater for their simultaneous remediation. The system was half biotic: the aquatic sediment on the anode side contained electro-active organisms, whilst the cathode side was abiotic. The aquatic sediment was used as an energy source to remediate nitrate and $\mathrm{Cr}(\mathrm{VI})$ contaminated groundwater. The system was economical because: (1) An easily created salt bridge was used; and (2) there was no need for additional carbon sources or applied potentials. Salt-bridge separation microbial fuel cell (MFC) have a low oxygen permeability that can ensure a longer electricity production duration than proton exchange membrane (PEM) separation MFC [26]. Our investigation, provides new insights regarding the simultaneous in situ treatment of groundwater and sediment remediation.

\section{Materials and Methods}

\subsection{Groundwater and Sediment}

- Synthetic groundwater

To replicate groundwater, nitrate with a concentration of $50 \mathrm{mg} / \mathrm{L}$ and $\mathrm{Cr}(\mathrm{VI})$ with a concentration of $2.5 \mathrm{mg} / \mathrm{L}$ (prepared using sodium nitrate $\left(\mathrm{NaNO}_{3}\right)$ and potassium dichromate $\left(\mathrm{K}_{2} \mathrm{Cr}_{2} \mathrm{O}_{7}\right)$ ) were added to deionized water. To ensure the conductivity of the synthetic groundwater, sodium sulfate $\left(\mathrm{Na}_{2} \mathrm{SO}_{4}\right)$ was added with a concentration of $0.5 \mathrm{~g} / \mathrm{L}$.

\section{- $\quad$ Sediment}

The sediment sample (62.33 g organic matter/ kg dry sediment) was collected from ChaoBai River (northeast of Beijing) at the depth of 5-10 cm below the sediment surface, and the overlying water was odorous and black. It was placed into a self-sealing bag and transported to the laboratory at $4{ }^{\circ} \mathrm{C}$. After the removal of plant debris, it was stirred with steel shovel for homogeneity, and then added to reactors respectively.

\subsection{Self-Powered System Construction}

A salt bridge was prepared by adding $3 \%$ agar and $30 \% \mathrm{KCl}$ to deionized water, heating and agitating it to completely dissolve the powder, and then pouring the solution into a rubber hose [27].

For the carbon felt pretreatment, new electrodes were soaked in $1 \mathrm{~mol} / \mathrm{L} \mathrm{HCl}$ and $1 \mathrm{~mol} / \mathrm{L} \mathrm{NaOH}$ to remove possible metal contamination, and then washed with deionized water for later use [28]. 
Five similar, H-type dual-chambered self-powered reactors were constructed, as shown in Figure 1. The preliminary experiment showed that the experiment error was below $5 \%$, so no contrast systems were constructed. The anode and cathode chamber volumes were both $250 \mathrm{~mL}$; carbon felt $(5 \mathrm{~cm} \times 4 \mathrm{~cm}$ $\times 0.5 \mathrm{~cm}$ ) was placed in each chamber; all cathode chambers contained $250 \mathrm{~mL}$ synthetic groundwater and all bottles were sealed with plastic films for the maintenance of an anoxic environment; meanwhile, all anode chambers were added with $200 \mathrm{~g}$ aquatic sediment for the coverage of electrodes, then covered with $2 \mathrm{~cm}$ water from the river for the imitation of real river circumstances; the circuits of all the reactors were closed with a titanium wire connecting a $1000 \Omega$ resistor to the electrodes; all reactors were separated by self-made salt bridges. Different ion containing synthetic groundwater was added to each of them. Reactor 1 contained synthetic groundwater contaminated by $\mathrm{NO}_{3}{ }^{-}$and $\mathrm{Cr}(\mathrm{VI})$. Reactor 2 was constructed with a cathode solution comprising synthetic groundwater and an added phosphate buffer to maintain the cathode $\mathrm{pH}$ at 7.2 \pm 0.1 . To investigate the removal rates of $\mathrm{NO}_{3}{ }^{-}$ and $\mathrm{Cr}(\mathrm{VI})$, reactor 3 was constructed with only $\mathrm{NO}_{3}{ }^{-}$contained synthetic groundwater and reactor 4 was constructed with only $\mathrm{Cr}(\mathrm{VI})$ added to the synthetic groundwater. To test whether there was a competitive reaction between the reduction of $\mathrm{NO}_{3}{ }^{-}$and $\mathrm{SO}_{4}{ }^{2-}$, reactor 5 with only $\mathrm{SO}_{4}{ }^{2-}$ added in the solution of cathodic chamber was constructed.

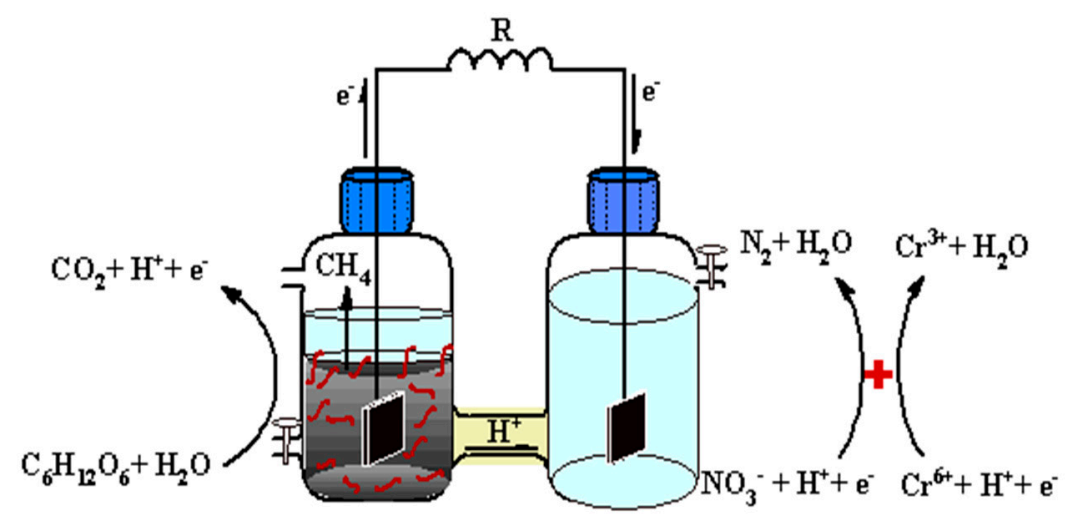

Figure 1. Self-powered system for nitrate and $\mathrm{Cr}(\mathrm{VI})$ removal from groundwater and simultaneous sediment remediation.

\subsection{Analysis and Calculation}

- Analysis Methods

The concentrations of nitrate $\left(\mathrm{NO}_{3}{ }^{-}-\mathrm{N}\right)$, nitrite $\left(\mathrm{NO}_{2}{ }^{-}-\mathrm{N}\right)$, and ammonia $\left(\mathrm{NH}_{4}{ }^{+}-\mathrm{N}\right)$ were determined by standard colorimetric methods using a spectrophotometer (DR/5000, USA). The $\mathrm{Cr}(\mathrm{VI})$ concentration was determined using the 1,5-diphenylcarbazide spectrophotometry method $\mathrm{HACH} / \mathrm{DR} 2800)$. The sulfate $\left(\mathrm{SO}_{4}{ }^{2-}\right)$ concentration was determined by ion liquid chromatography (ICS 2000, USA). The $\mathrm{pH}$ in the cathode was measured using a portable $\mathrm{pH}$ meter (Japan). The amount of organic matter in the sediment was measured using a HACH/DR2800. The voltage was recorded every $1 \mathrm{~min}$, using a digital multi-meter (2700, Keithley Instruments, Inc., Cleveland, OH, USA).

Cyclic voltammetry (CV) experiments were carried out to investigate the behavior of the carbon felt cathodes during the electrolysis of the nitrate and sulfate, with and without buffer solutions. The experiments were run using a computer controlled CS300 electrochemical workstation (CHI 660D, Shanghai Chenhua instruments, China) and a three-electrode cell. Pt was chosen as the counter electrode and Saturated calomel electrode (SCE) as the reference electrode. The working anode was carbon felt with a size of $1 \mathrm{~cm} \times 1 \mathrm{~cm}$.

\section{- Calculation}

The removal rate (\%RE) of nitrate and $\mathrm{Cr}(\mathrm{VI})$ was calculated by the Equation $\% \mathrm{RE}=\frac{n_{0}-n}{n_{0}} \times 100 \%$, where $n_{0}$ is the initial moles of nitrate or $\mathrm{Cr}(\mathrm{VI})$, and $\mathrm{n}$ is the remaining moles of nitrate or $\mathrm{Cr}(\mathrm{VI})$. 


\section{Results and Discussions}

\subsection{Contaminants Removal}

As shown in Figure 2a, with an initial nitrate concentration of $50 \pm 1 \mathrm{mg} / \mathrm{L}$ at each cathode, after $72 \mathrm{~h}$ the nitrate removal rate for reactors 1,2 , and 3 reached $9.94 \%, 9.62 \%$, and 19.75\%, respectively, which corresponded to removal amounts of $77.50 \mathrm{mg} / \mathrm{m}^{3} \cdot \mathrm{h}, 70.96 \mathrm{mg} / \mathrm{m}^{3} \cdot \mathrm{h}$, and $140.83 \mathrm{mg} / \mathrm{m}^{3} \cdot \mathrm{h}$, respectively. Each reactor cathode contained synthetic groundwater with an initial $\mathrm{Cr}(\mathrm{VI})$ concentration of $2.5 \mathrm{mg} / \mathrm{L}$. As can be seen from Figure 2b, after $72 \mathrm{~h}$ of operation, $\mathrm{Cr}(\mathrm{VI})$ in the cathodes had decreased. The removal rates for reactors 1,2 , and 4 were $20.5 \%$ and $25.0 \%$ and $22.6 \%$, respectively, which corresponded to removal amounts of $7.50 \mathrm{mg} / \mathrm{m}^{3} \cdot \mathrm{h}, 8.75 \mathrm{mg} / \mathrm{m}^{3} \cdot \mathrm{h}$ and $8.33 \mathrm{mg} / \mathrm{m}^{3} \cdot \mathrm{h}$, respectively.
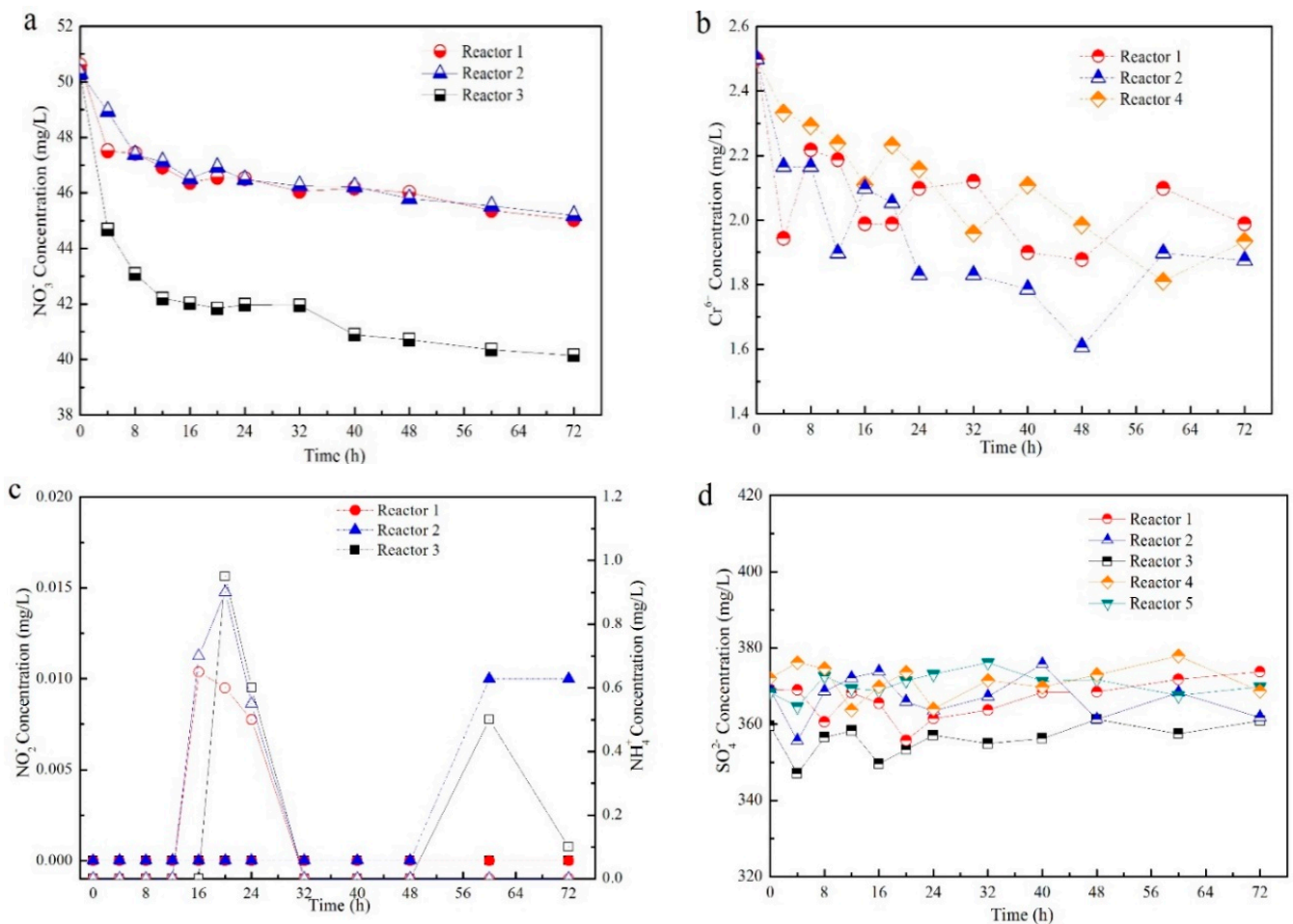

Figure 2. Contaminant removal in the cathode of the synthetic groundwater: (a) nitrate concentration variation; (b) $\mathrm{Cr}(\mathrm{VI})$ concentration variation; (c) nitrite (solid line) and ammonia (hollow line) concentration variation; and (d) sulfate concentration variation.

Nitrate, $\mathrm{Cr}(\mathrm{VI})$, and oxygen were electron acceptors for the semi-biodegradation systems. As shown in Figure 3, the electrochemically active micro-organisms in the sediment in the anodic chamber consumed the organic matter and generated protons $\left(\mathrm{H}^{+}\right)$, which were transferred from the anode to the cathode through the salt bridge. At the same time, electrons $\left(\mathrm{e}^{-}\right)$travelled to the cathodic chamber by an electric circuit and generated bio-energy. The protons and electrons were accepted by nitrate and $\mathrm{Cr}(\mathrm{VI})$ to form nitrogen (or nitrite) and $\mathrm{Cr}$ (III) [29]. By accepting protons and electrons, nitrate can be transformed into nitrite, nitrogen, or ammonia [30]. The reaction equations are as follows:

$$
\begin{aligned}
\mathrm{NO}_{3}^{-}+2 \mathrm{H}^{+}+2 \mathrm{e}^{-} & \leftrightarrow \mathrm{NO}_{2}^{-}+\mathrm{H}_{2} \mathrm{O} \\
\mathrm{NO}_{3}^{-}+6 \mathrm{H}^{+}+5 \mathrm{e}^{-} & \leftrightarrow \frac{1}{2} \mathrm{~N}_{2}+3 \mathrm{H}_{2} \mathrm{O} \\
\mathrm{NO}_{3}^{-}+9 \mathrm{H}^{+}+8 \mathrm{e}^{-} & \leftrightarrow \mathrm{NH}_{3}+3 \mathrm{H}_{2} \mathrm{O}
\end{aligned}
$$


With the acceptance of electrons, $\mathrm{Cr}(\mathrm{VI})$ can be reduced to $\mathrm{Cr}(\mathrm{III})$, which has a significantly reduced toxicity. The reaction equation for $\mathrm{Cr}(\mathrm{VI})$ to $\mathrm{Cr}(\mathrm{III})$ is:

$$
\mathrm{Cr}_{2} \mathrm{O}_{7}^{2-}+14 \mathrm{H}^{+}+6 \mathrm{e}^{-} \rightarrow 2 \mathrm{Cr}^{3+}+7 \mathrm{H}_{2} \mathrm{O}
$$

The composition of the organic matter in the sediment can be complex. We chose glucose to simulate the degradation of the organic matter, and the main reaction equation was:

$$
\left(\mathrm{CH}_{2} \mathrm{O}\right)_{\mathrm{n}}+\mathrm{n} \mathrm{H}_{2} \mathrm{O}+\mathrm{ne}^{-} \rightarrow \mathrm{nCO}_{2}+4 \mathrm{n} \mathrm{H}^{+}+4 \mathrm{ne}^{-}
$$

Only a few protons and electrons are needed in the reduction of nitrate to nitrogen, and in the oxidization of $\mathrm{Cr}(\mathrm{VI})$ to $\mathrm{Cr}(\mathrm{III})$. The theoretical glucose (organic matter) requirement for the removal of $\mathrm{Cr}(\mathrm{VI})$ and the conversion of nitrate to nitrogen is $0.433 \mathrm{~g}$-organic matter/g- $\mathrm{Cr}$ and $3.217 \mathrm{~g}$-organic matter/g- $N$, respectively. Thus, the organic matter needed in our experiment was very low, and energy generation by the river sediment was sufficient for the in situ remediation of $\mathrm{Cr}(\mathrm{VI})$ and nitrate polluted groundwater.

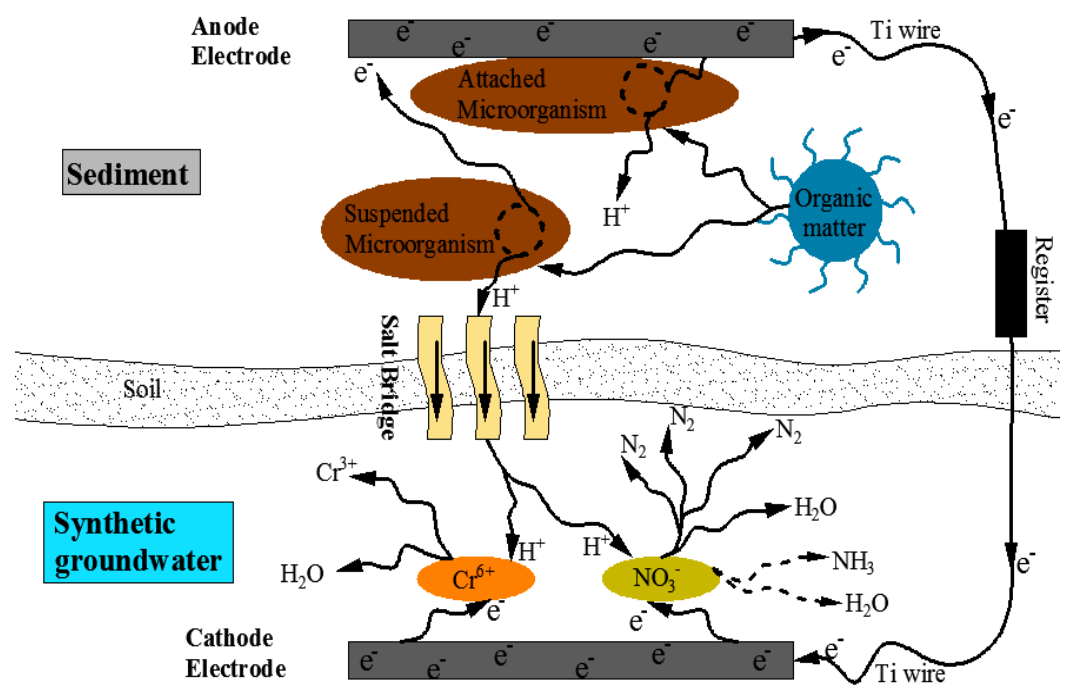

Figure 3. The process of nitrate and $\mathrm{Cr}(\mathrm{VI})$ removal from groundwater and sediment remediation in the self-powered system.

A gradual decline in nitrate concentration from $50 \mathrm{mg} / \mathrm{L}$ to around $40 \mathrm{mg} / \mathrm{L}$ was achieved during the 72-h operation. There was a significant difference between the removal rates of reactor 3 (no addition of $\mathrm{Cr}(\mathrm{VI})$ ) and the removal rates of reactors 1 and 2 . This difference indicated that the simultaneous existence of $\mathrm{Cr}(\mathrm{VI})$ with the nitrate could reduce the reduction rates for nitrate in the self-powered system. The nitrate concentration in the synthetic groundwater decreased quickly in the first $8 \mathrm{~h}$ and then decreased more slowly. The slowing in the rate of decrease was probably caused by changes in current generation related to the activity of electrochemically active microbes, and the degradation of organic matter in the anode. Initially, the easily biodegradable organics in the sediment were degraded and produced an abundance of protons and electrons that were transferred to the cathode and participated in nitrate removal reactions. With the depletion of easily degradable organic matters, then the refractory organics were slowly degraded, and the nitrate reduction rate slowed down. The buffer addition had no significant impact, which could be observed from the nitrate removal rates of nitrate. This was probably caused by the $\mathrm{pH}$, which remained close to neutral as in Figure 2a. A comparison between the nitrate decay in the environment [31] and in our system revealed that the rate of nitrate decay had been increased without any addition of extra energy. 
In addition, as shown in Figure 2c, neither nitrite nor ammonia accumulation were observed in the first $8 \mathrm{~h}$. The reduced $\mathrm{NO}_{3}{ }^{-}$was all converted to $\mathrm{N}_{2}$ or other gases [32]. Very little ammonia and nitrite were detected for the operation periods, possibly as a result of the system's low voltage.

To investigate the effects of the electrolyte $\mathrm{SO}_{4}{ }^{2-}$ on the $\mathrm{NO}_{3}{ }^{-}$removal rate, reactor 5 was constructed. As shown in Figure 2d, there was no degradation of $\mathrm{SO}_{4}{ }^{2-}$ concentration. This showed there was no competition between the degradation of $\mathrm{NO}_{3}{ }^{-}$and $\mathrm{SO}_{4}{ }^{2-}$.

Nitrate had a low impact on the removal of $\mathrm{Cr}(\mathrm{VI})$. This was shown by a comparison of the variations in $\mathrm{Cr}(\mathrm{VI})$ concentrations for reactors 4, 1, and 2 throughout the experiments. Although adding a buffer to stabilize $\mathrm{pH}$ around neutral had no significant effect on nitrate reduction, the reduction of $\mathrm{Cr}(\mathrm{VI})$ was significantly affected by the addition of the buffer. A comparison of reactors 1 and 2 suggested that a stable, neutral, $\mathrm{pH}$ facilitated $\mathrm{Cr}(\mathrm{VI})$ removal in the cathode. In addition, $\mathrm{Cr}(\mathrm{OH})_{3}$ also formed in the cathode because $\mathrm{Cr}(\mathrm{VI})$ reduced to $\mathrm{Cr}(\mathrm{III})$, which was easily precipitated as chromic hydroxide. Because there was consumption of $\mathrm{OH}^{-}$in the $\mathrm{Cr}(\mathrm{VI})$ cathode, the $\mathrm{pH}$ increase in the $\mathrm{Cr}(\mathrm{VI})$ cathode was slower than in the cathodes without $\mathrm{Cr}(\mathrm{VI})$, as shown in Figure 4 . The fluctuation in concentrations in the three reactors might have been related to the mass transfer of electrons and protons, which depended on the salt bridge resistance. The degradation of organic matter in sediment and sediment disturbance are major factors influencing the generation and transformation of protons and electrons. There were many worms in the sediment because of the sediment's high organic matter content [33]. The actions of the worms could strengthen the transfer rate of organic matters around the electrode, which would further influence the voltage output of the self-powered systems [34]. Furthermore, the instability in the self-powered systems could result in fluctuations in the $\mathrm{Cr}(\mathrm{VI})$ and nitrate removal rates.

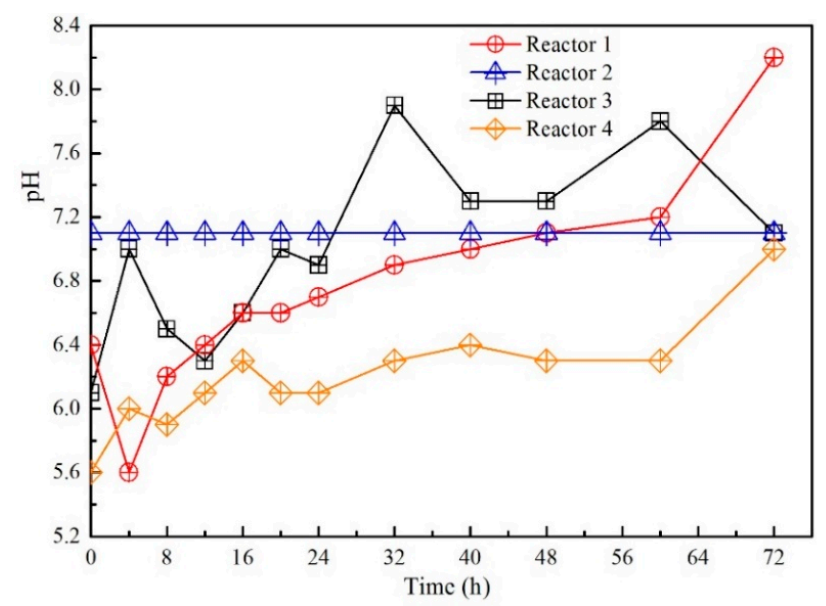

Figure 4. The $\mathrm{pH}$ variation in synthetic groundwater in the cathode. Reactor 1 (red), reactor 2 (blue), reactor 3 (black), and reactor 4 (orange).

\subsection{Electrochemical Analysis}

\subsubsection{Energy Generation}

The constructed self-powered systems can convert the chemical energy present in the organic matter in sediments to electricity (Figure 5a-d). Electricity was generated when the system was constructed. For the first $8 \mathrm{~h}$, every system's energy generation was almost equal to $6300 \mathrm{~A} / \mathrm{m}^{2}$. This similarity may have arisen because the bacteria and substances in each anodic chamber were similar. The electricity generation of reactor 3 decreased rapidly from $8300 \mathrm{~A} / \mathrm{m}^{2}$ to $1750 \mathrm{~A} / \mathrm{m}^{2}$, and then stabilized at around $1060 \mathrm{~A} / \mathrm{m}^{2}$ for the next $40 \mathrm{~h}$ (Figure $5 \mathrm{c}$ ). A similar decrease occurred at the other reactors, but at different times (Figure $5 \mathrm{a}, \mathrm{b}, \mathrm{d}$ ). These patterns were probably caused by a shortage of easily degradable organic matter near the anode [25]. The key factor in the decrease was probably 
the mass transfer limitation of the sediment, which hindered current production near the anode. In contrast, the next $40 \mathrm{~h}$ reactors containing $\mathrm{Cr}(\mathrm{VI})$ in the cathode generated more electricity (from 6356 $\mathrm{A} / \mathrm{m}^{2}$ to $8475 \mathrm{~A} / \mathrm{m}^{2}$ ) (Figure $5 \mathrm{a}, \mathrm{b}, \mathrm{d}$ ) than the one that did not. Although there was a fluctuation in the electricity generation from reactor 1 , the average current production trend was similar to that of reactor 4 and reactor 2 . These trends may have been related to the irregular distribution of organic matter in the sediment. Except for reactor 1, all the reactors reached a stable voltage output after $56 \mathrm{~h}$ of operation. However, the voltage output varied substantially with time. Each reactor reached a small peak in voltage output at the beginning of the experiment. This could be attributed to the presence of easily degradable components in the organic matter of the aquatic sediments. The voltage then dropped quickly because of the rapid consumption of the easily degradable components [35,36]. With the less degradable material remaining, to maintain the low-output voltage over time, the reactors reached their maximum voltage output (reactors 2 and 3 reached 19,068 A/ $\mathrm{m}^{2}$, reactor 4 reached $15,890 \mathrm{~A} / \mathrm{m}^{2}$, and reactor 1 reached $14,830 \mathrm{~A} / \mathrm{m}^{2}$ ). The output voltage of our self-powered system, utilizing a salt bridge as mediator, was lower than that of other research where PEM had been used as a mediator to produce power $[37,38]$. These differences might have been caused by the higher internal resistance of the salt bridge. The open-circuit voltages of the reactors were $14,830-18,010 \mathrm{~A} / \mathrm{m}^{2}$. This is somewhat higher than in previous studies [39], and may have resulted from the presence of worms in the anode sediments. Although the activity of the worms destroyed the anaerobic environment around the anode and destabilizes the self-powered systems [40], it could enhance the transfer of protons and electrons as well as accelerate the degradation of the organic matters by the augmentation of dissolved oxygen. Because the electrodes and sediments of the reactors were the same, the systems' resistance depended mostly on the solutions of the cathodes. With a buffer to stabilize the $\mathrm{pH}$ of the cathode, the voltage of reactor 2 was higher than that of reactor 1 and also more stable, indicating that the buffer could decrease the internal resistance [41,42].
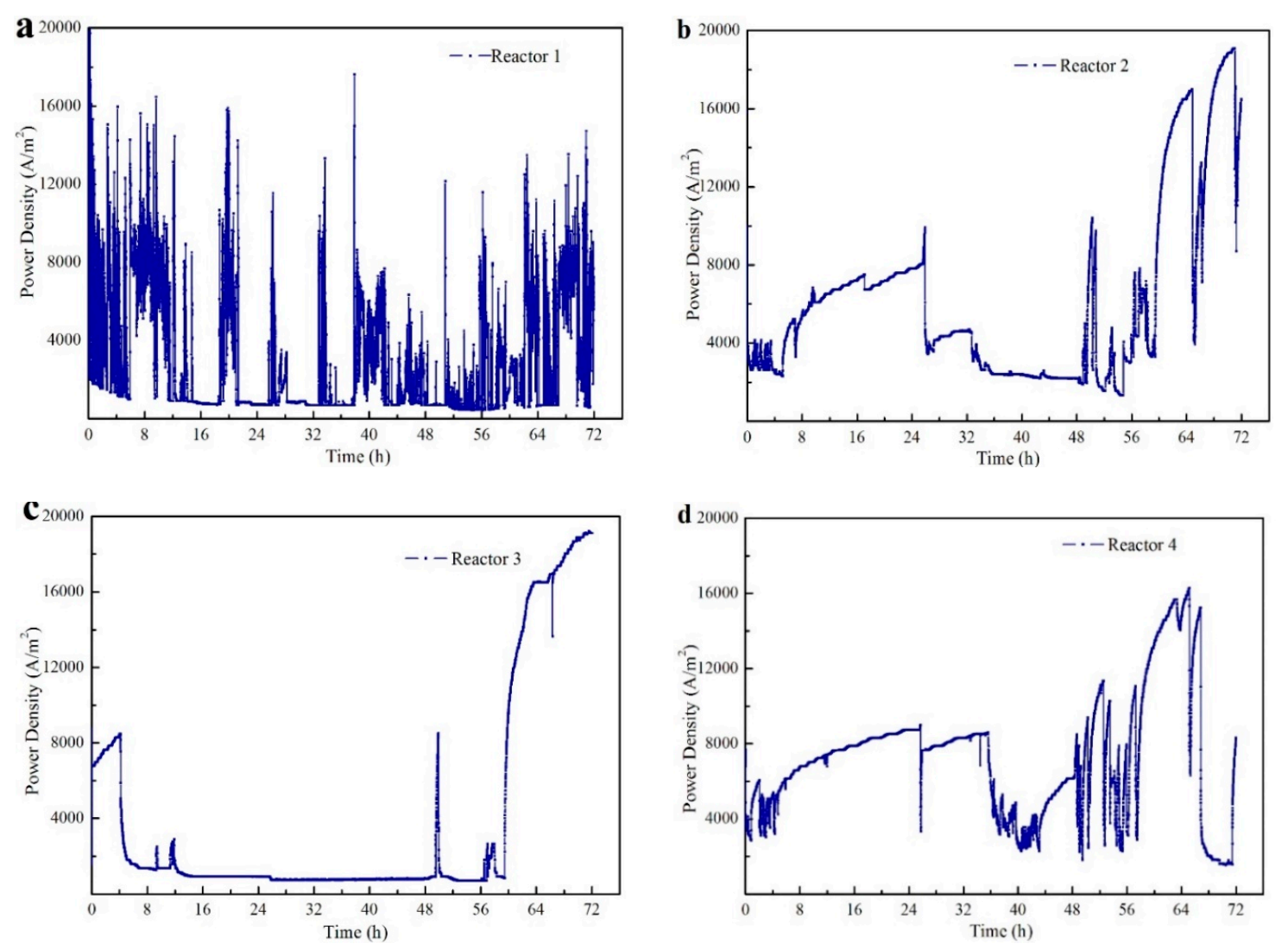

Figure 5. Electricity production in reactors 1, 2, 3, and 4 ((a), (b), (c), and (d), respectively). 


\subsubsection{Cyclic Voltammetry}

In addition, cyclic voltammetry was used to analyze the mechanisms involved in the electrochemical reduction of $\mathrm{Cr}(\mathrm{VI})$ and nitrate. Six different cathode solutions: Nitrate, $\mathrm{Cr}(\mathrm{VI})$, and a buffer, with and without sulfate (the concentration is similar to systems solution concentration) in aerobic conditions, were analyzed using the $\mathrm{CV}$ technique. The results are presented in Figure $6 \mathrm{a}-\mathrm{c}$. No redox peaks around -0.7 to $-0.8 \mathrm{~V}$ meant that in this experiment, there was no oxygen reduction [43]. The comparison between the solution with nitrate and $\mathrm{SO}_{4}{ }^{2-}$, and the solution with only $\mathrm{SO}_{4}{ }^{2-}$, showed that the reduction current peak was increased (Figure 6a), indicating that the addition of $\mathrm{SO}_{4}{ }^{2-}$ increased electrolyte levels, and then enhanced nitrate removal. The same result could be seen in Figure $6 \mathrm{~b}$, after the addition of $\mathrm{Cr}(\mathrm{VI})$; the current peak increased slightly, although less than the addition of $\mathrm{SO}_{4}{ }^{2-}$. After adding buffer to nitrate contaminated groundwater and $\mathrm{Cr}(\mathrm{VI})$ contaminated groundwater, the scanning area of both increased slightly as a result of the enhancement in conductivity. It could be concluded that the buffer had only a small influence on the nitrate removal rate (Figure 2a), but a much larger influence on the $\mathrm{Cr}(\mathrm{VI})$ removal rate (Figure $2 \mathrm{~b}$ ). However, adding $\mathrm{Cr}(\mathrm{VI})$ to the nitrate decreased the scanning area in comparison to the nitrate-only solution (Figure $6 \mathrm{c}$ ). This indicated that the presence of $\mathrm{Cr}(\mathrm{VI})$ could affect nitrate removal from groundwater, as shown by the results of the experiment.
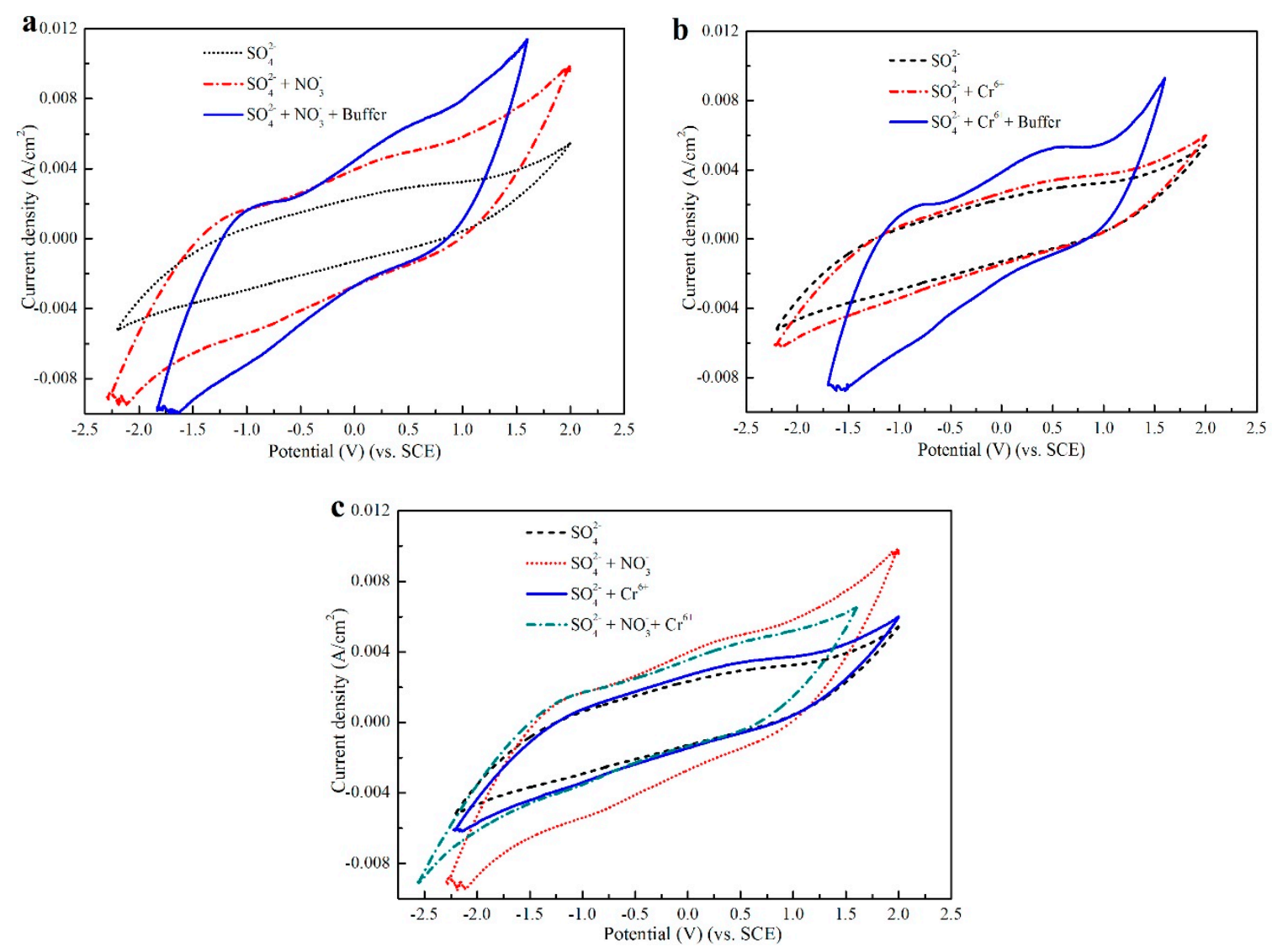

Figure 6. Cyclic voltammograms of the cathode electrode (carbon felt): (a) Comparison of nitrate, and nitrate with buffer; (b) comparison of $\mathrm{Cr}(\mathrm{VI})$, and $\mathrm{Cr}(\mathrm{VI})$ with buffer, and (c) comparison of different pollutants' cyclic voltammograms.

\section{Conclusions}

A self-powered system to reduce contaminants was successfully constructed. The system had synthetic groundwater in the cathodic chamber and river sediment in the anodic chamber. The system 
utilized carbon to produce energy for contaminant reduction in the cathode. In the system, nitrate and $\mathrm{Cr}(\mathrm{VI})$ contaminants were transformed into nitrogen and $\mathrm{Cr}(\mathrm{III})$, respectively. It was observed that in the simultaneous treatment of nitrate and $\mathrm{Cr}(\mathrm{VI})$ coexisting in the synthetic groundwater, $\mathrm{Cr}(\mathrm{VI})$ had a significant inhibiting effect on the removal of nitrate. However, $\mathrm{SO}_{4}{ }^{2-}$ had no effect on the removal of nitrate. Although $\mathrm{pH}$ stabilization with a phosphate buffer addition had no obvious effect on nitrate removal, it enhanced the reduction of $\mathrm{Cr}(\mathrm{VI})$. Given there was no efficient method for interim removal of groundwater pollution and aquatic sediment treatment, using salt bridge as a connection in the self-powered system could be a good choice for those treatments.

Author Contributions: L.H. performed the experiments, analyzed the data and wrote the paper; M.L. provided ideas and revised the paper; R.L. analyzed the data; N.Z., F.Z. and X.L. checked and approved the final manuscript.

Funding: This research was funded by Beijing Natural Science Foundation (J150004).

Conflicts of Interest: The authors declare no conflicts of interest.

\section{References}

1. Zhai, Y.; Zhao, X.; Teng, Y.; Li, X.; Zhang, J.; Wu, J.; Zuo, R. Groundwater nitrate pollution and human health risk assessment by using hhra model in an agricultural area, NE China. Ecotoxicol. Environ. Saf. 2017, 137, 130-142. [CrossRef] [PubMed]

2. Zhang, S.; Mao, G.; Crittenden, J.; Liu, X.; Du, H. Groundwater remediation from the past to the future: A bibliometric analysis. Water Res. 2017, 119, 114-125. [CrossRef] [PubMed]

3. Anornu, G.; Gibrilla, A.; Adomako, D. Tracking nitrate sources in groundwater and associated health risk for rural communities in the white volta river basin of ghana using isotopic approach $\left(\delta^{15} \mathrm{~N}, \delta^{18} \mathrm{ONO}_{3}\right.$ and ${ }^{3}$ H). Sci. Total Environ. 2017, 603, 687-698. [CrossRef] [PubMed]

4. Costa, M.; Klein, C.B. Toxicity and carcinogenicity of chromium compounds in humans. Crit. Rev. Toxicol. 2006, 36, 155-163. [CrossRef] [PubMed]

5. Naz, A.; Mishra, B.K.; Gupta, S.K. Human health risk assessment of chromium in drinking water: A case study of sukinda chromite mine, Odisha, India. Expo. Health 2016, 8, 253-264. [CrossRef]

6. Elisante, E.; Muzuka, A.N.N. Assessment of sources and transformation of nitrate in groundwater on the slopes of Mount Meru, Tanzania. Environ. Earth Sci. 2016, 75, 277. [CrossRef]

7. Ju, X.T.; Kou, C.L.; Zhang, F.S.; Christie, P. Nitrogen balance and groundwater nitrate contamination: Comparison among three intensive cropping systems on the North China Plain. Environ. Pollut. 2006, 143, 117-125. [CrossRef] [PubMed]

8. $\quad$ Kazakis, N.; Kantiranis, N.; Kalaitzidou, K.; Kaprara, E.; Mitrakas, M.; Frei, R.; V-Argemezis, G.; Tsourlos, P.; Zouboulis, A.; Filippidis, A. Origin of hexavalent chromium in groundwater: The example of Sarigkiol Basin, Northern Greece. Sci. Total Environ. 2017, 593, 552-566. [CrossRef] [PubMed]

9. Afzal, M.; Shabir, G.; Iqbal, S.; Mustafa, T.; Khan, Q.M.; Khalid, Z.M. Assessment of heavy metal contamination in soil and groundwater at leather industrial area of Kasur, Pakistan. Clean-Soil Air Water 2014, 42, 1133-1139. [CrossRef]

10. Lelli, M.; Grassi, S.; Amadori, M.; Franceschini, F. Natural Cr(VI) contamination of groundwater in the cecina coastal area and its inner sectors (Tuscany, Italy). Environ. Earth Sci. 2014, 71, 3907-3919. [CrossRef]

11. Liu, J.; Ding, Y.; Ji, L.; Zhang, X.; Yang, F.; Wang, J.; Kang, W. Highly sensitive detection of Cr(VI) in groundwater by bimetallic NiFe nanoparticles. Anal. Methods 2017, 9, 1031-1037. [CrossRef]

12. Zhai, S.; Zhao, Y.; Ji, M.; Oi, W. Simultaneous removal of nitrate and chromate in groundwater by a spiral fiber based biofilm reactor. Bioresour. Technol. 2017, 232, 278-284. [CrossRef] [PubMed]

13. Sahinkaya, E.; Yurtsever, A.; Ucar, D. A novel elemental sulfur-based mixotrophic denitrifying membrane bioreactor for simultaneous $\mathrm{Cr}(\mathrm{VI})$ and nitrate reduction. J. Hazard. Mater. 2017, 324, 15-21. [CrossRef] [PubMed]

14. Ranieri, E.; Fratino, U.; Petrella, A.; Torretta, V.; Rada, E.C. Ailanthus Altissima and Phragmites Australis for chromium removal from a contaminated soil. Environ. Sci. Pollut. Res. 2016, 23, 15983-15989. [CrossRef] [PubMed] 
15. Sun, M.; Zhang, G.; Qin, Y.H.; Cao, M.J.; Liu, Y.; Li, J.H.; Qu, J.H.; Liu, H.J. Redox conversion of chromium(VI) and arsenic(III) with the intermediates of chromium(V) and arsenic(IV) via AuPd/CNTs electrocatalysis in acid aqueous solution. Environ. Sci. Technol. 2015, 49, 9289-9297. [CrossRef] [PubMed]

16. Chen, D.; Wang, H.; Yang, K. Effective biodegradation of nitrate, $\mathrm{Cr}(\mathrm{VI})$ and p-fluoronitrobenzene by a novel three dimensional bioelectrochemical system. Bioresour. Technol. 2016, 203, 370-373. [CrossRef] [PubMed]

17. Salomons, W.; Derooij, N.M.; Kerdijk, H.; Bril, J. Sediments as a source for contaminants. Hydrobiologia 1987, 149, 13-30. [CrossRef]

18. Kilunga, P.I.; Sivalingam, P.; Laffite, A.; Grandjean, D.; Mulaji, C.K.; de Alencastro, L.F.; Mpiana, P.T.; Pote, J. Accumulation of toxic metals and organic micro-pollutants in sediments from tropical urban rivers, Kinshasa, Democratic Republic of the Congo. Chemosphere 2017, 179, 37-48. [CrossRef] [PubMed]

19. Perelo, L.W. Review: In Situ and bioremediation of organic pollutants in aquatic sediments. J. Hazard. Mater. 2010, 177, 81-89. [CrossRef] [PubMed]

20. Lau, S.S.S.; Chu, L.M. Contaminant release from sediments in a coastal wetland. Water Res. 1999, 33, 909-918. [CrossRef]

21. Rekha, P.; Suman Raj, D.S.; Aparna, C.; Hima Bindu, V.; Anjaneyulu, Y. Bioremediation of contaminated lake sediments and evaluation of maturity indicies as indicators of compost stability. Int. J. Environ. Res. Public Health 2005, 2, 251-262. [CrossRef] [PubMed]

22. Wang, Y.; Wang, C.; Xu, S.; Zhang, D.; Zeng, L.; He, F.; Zhou, Q.; Wu, Z. Spatial and temporal variations of water-soluble organic carbon in surface sediments of west lake, Hangzhou. J. Hydroecol. 2015, 36, 57-62.

23. Feng, Y.; Lin, Y.; Zhang, X.; Xu, Y.; Yu, F.; Xu, J. Organic contamination in river sediment and its distribution characteristics in southern Jiangsu. J. Agro-Environ. Sci. 2007, 26, 1240-1244.

24. Sherafatmand, M.; Ng, H.Y. Using sediment microbial fuel cells (SMFCs) for bioremediation of polycyclic aromatic hydrocarbons (PAHs). Bioresour. Technol. 2015, 195, 122-130. [CrossRef] [PubMed]

25. Reimers, C.E.; Tender, L.M.; Fertig, S.; Wang, W. Harvesting energy from the marine sediment-water interface. Environ. Sci. Technol. 2001, 35, 192-195. [CrossRef] [PubMed]

26. Li, W.-W.; Sheng, G.-P.; Liu, X.-W.; Yu, H.-Q. Recent advances in the separators for microbial fuel cells. Bioresour. Technol. 2011, 102, 244-252. [CrossRef] [PubMed]

27. Sudarsan, J.S.; Prasana, K.; Nithiyanantham, S.; Renganathan, K. Comparative study of electricity production and treatment of different wastewater using microbial fuel cell (MFC). Environ. Earth Sci. 2015, 73, 2409-2413. [CrossRef]

28. Tang, Y.; Sun, Y.; Yu, J.; Liu, J.; Fu, J. Performance of chemically modified carbon felt air cathode with HNO_3. China Water Wastewater 2014, 30, 10-14.

29. Sophia, A.C.; Saikant, S. Reduction of chromium(VI) with energy recovery using microbial fuel cell technology. J. Water Process Eng. 2016, 11, 39-45. [CrossRef]

30. Jia, Y.-H.; Tran, H.-T.; Kim, D.-H.; Oh, S.-J.; Park, D.-H.; Zhang, R.-H.; Ahn, D.-H. Simultaneous organics removal and bio-electrochemical denitrification in microbial fuel cells. Bioprocess Biosyst. Eng. 2008, 31, 315-321. [CrossRef] [PubMed]

31. Robertson, W.D.; Blowes, D.W.; Ptacek, C.J.; Cherry, J.A. Long-term performance of in situ reactive barriers for nitrate remediation. Ground Water 2000, 38, 689-695. [CrossRef]

32. Dima, G.E.; de Vooys, A.C.A.; Koper, M.T.M. Electrocatalytic reduction of nitrate at low concentration on coinage and transition-metal electrodes in acid solutions. J. Electroanal. Chem. 2003, 554, 15-23. [CrossRef]

33. Xu, X.; Zhao, Q.; Wu, M.; Ding, J.; Zhang, W. Biodegradation of organic matter and anodic microbial communities analysis in sediment microbial fuel cells with/without Fe(III) oxide addition. Bioresour. Technol. 2017, 225, 402-408. [CrossRef] [PubMed]

34. Zhao, Q.; Li, R.Y.; Ji, M.; Ren, Z.J. Organic content influences sediment microbial fuel cell performance and community structure. Bioresour. Technol. 2016, 220, 549-556. [CrossRef] [PubMed]

35. He, Y.-R.; Xiao, X.; Li, W.-W.; Cai, P.-J.; Yuan, S.-J.; Yan, F.-F.; He, M.-X.; Sheng, G.-P.; Tong, Z.-H.; Yu, H.-Q. Electricity generation from dissolved organic matter in polluted lake water using a microbial fuel cell (MFC). Biochem. Eng. J. 2013, 71, 57-61. [CrossRef]

36. Xia, C.; Xu, M.; Liu, J.; Guo, J.; Yang, Y. Sediment microbial fuel cell prefers to degrade organic chemicals with higher polarity. Bioresour. Technol. 2015, 190, 420-423. [CrossRef] [PubMed] 
37. Sevda, S.; Sreekrishnan, T.R. Effect of salt concentration and mediators in salt bridge microbial fuel cell for electricity generation from synthetic wastewater. J. Environ. Sci. Health Part A 2012, 47, 878-886. [CrossRef] [PubMed]

38. Liu, Z.-D.; Li, H.-R. Effects of bio- and abio-factors on electricity production in a mediatorless microbial fuel cell. Biochem. Eng. J. 2007, 36, 209-214. [CrossRef]

39. Scott, K.; Cotlarciuc, I.; Hall, D.; Lakeman, J.B.; Browning, D. Power from marine sediment fuel cells: The influence of anode material. J. Appl. Electrochem. 2008, 38, 1313-1319. [CrossRef]

40. Zhao, Q.; Ji, M.; Li, R.; Ren, Z.J. Long-term performance of sediment microbial fuel cells with multiple anodes. Bioresour. Technol. 2017, 237, 178-185. [CrossRef] [PubMed]

41. Fan, Y.; Sharbrough, E.; Liu, H. Quantification of the internal resistance distribution of microbial fuel cells. Environ. Sci. Technol. 2008, 42, 8101-8107. [CrossRef] [PubMed]

42. Min, B.; Roman, O.B.; Angelidaki, I. Importance of temperature and anodic medium composition on microbial fuel cell (MFC) performance. Biotechnol. Lett. 2008, 30, 1213-1218. [CrossRef] [PubMed]

43. Sun, M.; Liu, H.J.; Liu, Y.; Qu, J.H.; Li, J.H. Graphene-based transition metal oxide nanocomposites for the oxygen reduction reaction. Nanoscale 2015, 7, 1250-1269. [CrossRef] [PubMed]

(C) 2018 by the authors. Licensee MDPI, Basel, Switzerland. This article is an open access article distributed under the terms and conditions of the Creative Commons Attribution (CC BY) license (http:/ / creativecommons.org/licenses/by/4.0/). 